\title{
Contribution of plasmid-encoded peptidase S8 (PrtP) to adhesion and transit in the gut of Lactococcus lactis IBB477 strain
}

\author{
Joanna Maria Radziwill-Bienkowska ${ }^{1}$. Véronique Robert ${ }^{2} \cdot$ Karolina Drabot $^{1,3} \cdot$ \\ Florian Chain $^{2}$ - Claire Cherbuy ${ }^{2} \cdot$ Philippe Langella $^{2} \cdot$ Muriel Thomas $^{2}$ • \\ Jacek Karol Bardowski $^{1} \cdot$ Muriel Mercier-Bonin ${ }^{2,4} \cdot$ Magdalena Kowalczyk $^{1}$ (i)
}

Received: 14 January 2017 /Revised: 25 April 2017 / Accepted: 6 May 2017 /Published online: 24 May 2017

(C) The Author(s) 2017. This article is an open access publication

\begin{abstract}
The ability of Lactococcus lactis to adhere to the intestinal mucosa can potentially prolong the contact with the host, and therefore favour its persistence in the gut. In the present study, the contribution of plasmid-encoded factors to the adhesive and transit properties of the L. lactis subsp. cremoris IBB477 strain was investigated. Plasmid-cured derivatives as well as deletion mutants were obtained and analysed. Adhesion tests were performed using non-coated polystyrene plates, plates coated with mucin or fibronectin and mucus-secreting HT29-MTX intestinal epithelial cells. The results indicate that two plasmids, pIBB477a and $b$, are involved in adhesion of the IBB477 strain. One of the genes localised on plasmid pIBB477b (AJ89_14230), which encodes cell wall-associated peptidase S8 (PrtP), mediates adhesion of the IBB477 strain to bare, mucin- and fibronectincoated polystyrene, as well as to HT29-MTX cells. Interactions between bacteria and mucus secreted by HT29MTX cells were further investigated by fluorescent staining and confocal microscopy. Confocal images showed that IBB477 forms dense clusters embedded in secreted mucus. Finally, the ability of IBB477 strain and its $\Delta$ prtP deletion mutant to colonise the gastrointestinal tract of conventional
\end{abstract}

Magdalena Kowalczyk

mk@ibb.waw.pl

1 Institute of Biochemistry and Biophysics, Polish Academy of Sciences, Pawinskiego 5A, 02-106 Warsaw, Poland

2 Micalis Institute, INRA, AgroParisTech, Université Paris-Saclay, 78350 Jouy-en-Josas, France

3 Warsaw University of Life Sciences-SGGW, Nowoursynowska 166, 02-787 Warsaw, Poland

4 Present address: Toxalim (Research Centre in Food Toxicology) UMR INRA 1331, 180 chemin de Tournefeuille, BP 93173, 31027 Toulouse cedex 3, France
C57Bl/6 mice was determined. Both strains were present in the gut for up to $72 \mathrm{~h}$. In summary, adhesion and persistence of IBB477 were analysed by in vitro and in vivo approaches, respectively. Our studies revealed that plasmidic genes encoding cell surface proteins are more involved in the adhesion of IBB477 strain than in the ability to confer a selective advantage in the gut.

Keywords Lactococcus lactis · Adhesion · PrtP · HT29-MTX cell line $\cdot$ Confocal microscopy $\cdot$ C57B1/6 mice

\section{Introduction}

Lactococcus lactis is one of the most widely used lactic acid bacterium (LAB) in the dairy industry. It serves as a starter culture for the production of a variety of cheeses, as well as other dairy products such as sour cream and buttermilk. Owing to the long history of safe consumption and the availability of molecular tools, lactococci have a great potential as mucosal delivery vehicles for therapeutic and prophylactic molecules (Bermudez-Humaran et al. 2011; Hugentobler et al. 2012; del Carmen et al. 2013; Szatraj et al. 2014; Kasarełło et al. 2016). The ability of $L$. lactis to adhere to the intestinal mucosa can potentially prolong the contact with the host, and therefore favour its persistence in the gut. After consumption, L. lactis is confronted to the digestive tract harsh conditions, and in this context, we tested if the contribution of the adhesion-mediating factors could confer a selective advantage in the gut.

L. lactis strains characteristically contain many plasmids that vary in size and copy number. These plasmids encode numerous traits of biotechnological significance, including lactose and casein utilisation, flavour development, stress response, bacteriophage resistance and production of 
bacteriocins (for review, see Ainsworth et al. 2014). Recent studies indicate that some of the genes localised on lactococcal plasmids are potentially involved in adhesion of $L$. lactis to the intestinal mucosa. The $p r t P$ gene from $\mathrm{pWV} 05$ plasmid of the L. lactis $\mathrm{Wg} 2$ strain, coding for the cell wall-anchored proteinase, was shown to enhance cell hydrophobicity and adhesion to solid surfaces (Habimana et al. 2007). Two genes localised on the pKP1 plasmid of L. lactis BGKP1 strain, aggL and $m b p L$, encoding aggregation and mucin-binding proteins, were reported to mediate adhesion to HT29-MTX cells and colonic mucus, respectively (Lukić et al. 2012). Two plasmid genes with key roles in adhesion were also identified in L. lactis TIL448 strain, $y h g E 2$ gene coding for backbone pilin, which was shown to be involved in adhesion of TIL448 to Caco-2 cell line, and muc gene coding for mucus-binding protein (Meyrand et al. 2013). Both genes were found to contribute to the ability of TIL448 strain to adhere to pig gastric mucin (PGM) under static and dynamic conditions (Le et al. 2013). For L. lactis subsp. cremoris IBB477, the model strain in the present study, eight proteins out of 63 predicted by PSORTb as extracellular or cell wall attached are localised on its plasmids (Radziwill-Bienkowska et al. 2016). Taking into account that cell surface-associated macromolecules are considered to play an important role in the adhesion of LAB to the gastrointestinal tract (GIT), the nature and functional role of plasmidic genes in IBB477 adhesive phenotype remain to be unravelled.

Bacteria can attach to different components of the intestinal mucosa, in particular mucins and proteins of the extracellular matrix (ECM), such as laminin, collagen and fibronectin (Vélez et al. 2007). A well-established in vitro model to study bacterial adhesion is the mucus-secreting HT29-MTX cell line, a homogenous subpopulation of goblet cells selected from a mostly undifferentiated human colon carcinoma HT29 cell population after growth adaptation to anti-cancer drug methotrexate (MTX) (Lesuffleur et al. 1990). Owing to its mucus-secreting phenotype, the HT29-MTX cell line is widely used to investigate adhesive properties of bacteria (Coconnier et al. 1992; Gopal et al. 2001; de los ReyesGavilán et al. 2011; Turpin et al. 2012; Kebouchi et al. 2016).

Adhesion may confer a selective advantage for transient foodborne bacteria to persist within the GIT, even though consistent experimental evidence is still lacking. In the studies reported by Turpin et al. (2012, 2013), three lactobacilli, namely Lactobacillus fermentum, Lactobacillus paraplantarum and Lactobacillus salivarius, displayed equivalent adhesive properties to HT29-MTX cells and to their non-mucus-secreting counterparts HT29 (Turpin et al. 2012), even though in gnotobiotic rats inoculated with the same bacteria as a cocktail, their colonisation profiles were clearly different (Turpin et al. 2013). Regarding L. lactis, its ability to survive the gastrointestinal transit is well documented (Klijn et al. 1995; Drouault et al. 1999; Kimoto et al. 2003). In a very recent study on the CNCM I-1631 strain, its longer persistence in a subgroup of rats exhibiting a "permissive" phenotype of microbiota was possibly attributed to its ability to adhere to the intestinal mucosa (Zhang et al. 2016). Indeed, deletion of srtA gene encoding housekeeping sortase A resulted in a shorter persistence of the CNCM I-1631 strain in the permissive rat subgroup. However, when introduced in rodents associated with single or multiple bacterial strains, the ability of $L$. lactis to persist in the gut varied between the studies (Schlundt et al. 1994; Brockmann et al. 1996; Alpert et al. 2003; Boguslawska et al. 2009; McNulty et al. 2011). In the GIT of germ-free animals, like in mice, $L$. lactis is able to efficiently colonise and persist when inoculated as a single strain (Gruzza et al. 1992; Corthier et al. 1998; Roy et al. 2008). Moreover, some particular strains, such as L. lactis IBB477 and L. lactis CNCM I-1631, are able to persist in the GIT of gnotobiotic animals for the entire monitoring period (at least 2 weeks) (Boguslawska et al. 2009; McNulty et al. 2011). In humans, although lactococci are not a frequent element of intestinal microbiota, their presence in faeces was detected in several studies (Finegold et al. 1983; Millette et al. 2007; Lakshminarayanan et al. 2013; David et al. 2014).

The L. lactis subsp. cremoris IBB477 strain, originally isolated from raw cow milk in Poland, was demonstrated to possess adhesive properties towards bare and PGM-coated polystyrene at the single-cell level, by atomic force microscopy (AFM) (Le et al. 2011), as well as at the bacterial population level (Le et al. 2012; Radziwill-Bienkowska et al. 2014), and recently under dynamic conditions, using a shear stress flow chamber (Radziwill-Bienkowska et al. 2016). Owing to its adhesive properties, IBB477 (called for the purpose of the cited publication L. lactis subsp. cremoris IBB SC1) was used as a potential probiotic strain and was shown to survive in the chicken guts throughout their lifespan (42 days) (Sławińska et al. 2014). Furthermore, the IBB477 was selected as a candidate strain for development of an oral protective vaccine against avian influenza virus infections (Radziwill-Bienkowska et al. 2014). As we are interested in mechanisms of adhesion with special respect to the Lactococcus genus, our studies focus on the identification of molecular factors involved in adhesion of L. lactis subsp. cremoris IBB477 to the intestinal mucosa. Based on genomic analysis, putative adhesins of IBB477 strain were identified and the role in adhesion of one of the chromosomal genes (AJ89_07570) was confirmed (Radziwill-Bienkowska et al. 2016). In the present study, contribution of plasmid-encoded factors to adhesive properties of IBB477 strain was investigated. Plasmid-cured derivatives as well as deletion mutants were obtained and analysed. Adhesion tests were performed using noncoated and coated polystyrene plates and the mucus-secreting HT29-MTX cell line. Interactions between bacteria and mucus secreted by HT29-MTX cells were visualised by fluorescent staining and confocal microscopy. Finally, the resistance to digestive stress and the ability of IBB477 and selected deletion mutant to colonise the GIT of conventional $\mathrm{C} 57 \mathrm{BI} / 6$ mice were determined. 


\section{Materials and methods}

\section{Bacterial strains and growth conditions}

Bacterial strains used in this study are listed in Table 1. The L. lactis IBB477 strain originates from the samples of raw cow milk collected in Poland at the turn of the century (Zycka-Krzesinska et al. 2015). Bacterial strains were generally cultured and stored as previously described (RadziwillBienkowska et al. 2016). For the adhesion test to HT29-MTX cells and the digestive stress test, bacterial strains were grown at $37^{\circ} \mathrm{C}$. In experiments with HT29-MTX cells, the strains were incubated in cell culture medium with reduced foetal bovine serum (FBS) $[2 \%(v / v)]$. For construction of deletion mutants, the growth medium was supplemented with erythromycin (Em; $100 \mu \mathrm{g} \mathrm{ml}^{-1}$ for $E$. coli and $5 \mu \mathrm{g} \mathrm{ml}^{-1}$ for L. lactis) and specific temperatures were applied as described previously (RadziwillBienkowska et al. 2016). In in vivo studies, bacteria were counted by plating mice faeces on M17-glucose $(0.5 \% w / v$; M17; Oxoid Ltd., Basingstoke, Hampshire, UK) supplemented with nalidixic acid $\left(\mathrm{Nal} ; 40 \mu \mathrm{g} \mathrm{ml}^{-1}\right)$ and Tet $\left(100 \mu \mathrm{g} \mathrm{ml}^{-1}\right.$ —concentration necessary for elimination of $\operatorname{Tet}^{\mathrm{r}}$ Enterococcus spp. present in faeces and permissive for the IBB477 strain) at $30^{\circ} \mathrm{C}$.

\section{Plasmid-curing method}

The plasmid-free derivatives obtained in this study are presented in Table 1. Plasmid curing was performed by growth passages. A $10^{3}$-fold dilution of the saturated culture of IBB477 or its plasmid-free derivatives in M17-glucose medium with Tet was incubated for $72 \mathrm{~h}$ at $30{ }^{\circ} \mathrm{C}$ and used for inoculation of the subsequent passage. Appropriate dilutions of selected passages were plated on M17-glucose medium with Tet or in the absence of Tet in the case of plasmid pIBB477a curing, for which tetracycline-sensitive colonies were isolated on M17-glucose medium without antibiotic selection and compared with replicates on plates with Tet. The presence of other plasmids was analysed using multiplex colony PCR with primer pairs specific for each plasmid (Table 2). For all unique derivatives with different plasmid content, the absence of a single plasmid was verified using PCR with another primer pair (Table 2). In addition, to compare plasmid profiles, plasmid DNA was isolated using the Plasmid Midi AX purification kit (A\&A Biotechnology, Gdynia, Poland) preceded by incubation in TES-lysozyme $\left(10 \mathrm{mg} \mathrm{ml}^{-1}\right)$ for $40 \mathrm{~min}$ at $43{ }^{\circ} \mathrm{C}$. Plasmid DNA was then digested with EcoRI or HindIII restriction enzymes according to the

Table 1 Bacterial strains used in this study

\begin{tabular}{|c|c|c|}
\hline Strain $^{\mathrm{a}}$ & Relevant characteristic(s) & Source and/or reference \\
\hline \multicolumn{3}{|l|}{ E. coli } \\
\hline TG1 & $\begin{array}{l}\Delta(\text { hsdMS-mcr }) 5 \Delta(\text { lac-proAB) supE thil } \mathrm{F} \\
\quad(\text { traD36 proAB } \\
\left.\text { lacl }^{q} Z \Delta M 15\right)\end{array}$ & Carter et al. (1985) \\
\hline $\mathrm{EC} 1000$ & $\begin{array}{l}\mathrm{Km}^{\mathrm{r}} \text {, RepA }{ }^{+} \mathrm{MC} 1000 \text {, carrying a single copy of the } \mathrm{p} \\
\text { WV01 repA gene in the } \operatorname{glg} B \text { gene }\end{array}$ & Leenhouts et al. (1991) \\
\hline \multicolumn{3}{|l|}{ L. lactis subsp. lactis } \\
\hline IL1403 & Plasmid-free wild-type, low-adhesive control strain & $\begin{array}{l}\text { INRA, Jouy-en-Josas, France } \\
\text { (Chopin et al. 1984) }\end{array}$ \\
\hline \multicolumn{3}{|l|}{ L. lactis subsp. cremoris } \\
\hline MG1820 & MG1363 carrying plasmid pMG820, low-adhesive control strain & $\begin{array}{l}\text { LISBP, Université de Toulouse, CNRS, INRA, } \\
\text { INSA, Toulouse, France (Maeda and } \\
\text { Gasson 1986) }\end{array}$ \\
\hline IBB477 & Wild-type strain, $\mathrm{Tc}^{\mathrm{r}}$ & IBB PAS, Warsaw, Poland \\
\hline IBB3171 (-a) & IBB477-derivative, -pIBB477a, $\mathrm{Tc}^{\mathrm{s}}$ & This study \\
\hline IBB3172 (-b) & IBB477-derivative, -pIBB477b, $\mathrm{Tc}^{\mathrm{r}}$ & This study \\
\hline IBB3176 (-c) & IBB477-derivative, - pIBB477c, $\mathrm{Tc}^{\mathrm{r}}$ & This study \\
\hline IBB3178 (-d) & IBB477-derivative, -pIBB477d, $\mathrm{Tc}^{\mathrm{r}}$ & This study \\
\hline IBB3173 (-ab) & IBB477-derivative, -pIBB477a, -pIBB477b, $\mathrm{Tc}^{\mathrm{s}}$ & This study \\
\hline IBB3177 (-ac) & IBB477-derivative, -pIBB477a, -pIBB477c, Tc ${ }^{\mathrm{s}}$ & This study \\
\hline IBB3177 (-ad) & IBB477-derivative, -pIBB477a, -pIBB477d, $\mathrm{Tc}^{\mathrm{s}}$ & This study \\
\hline IBB3174 (-bc) & IBB477-derivative, -pIBB477b, -pIBB477c, $\mathrm{Tc}^{\mathrm{r}}$ & This study \\
\hline IBB3175 (-abc) & IBB477-derivative, -pIBB477a, -pIBB477b, -pIBB477c, Tc ${ }^{\mathrm{s}}$ & This study \\
\hline IBB3189 $(\Delta 14140)$ & IBB477 $\Delta$ AJ89_14140, $\mathrm{Tc}^{\mathrm{r}}$ & This study \\
\hline IBB3190 $(\Delta$ prtP $)$ & IBB477 $\Delta$ AJ89_14230, $\mathrm{Tc}^{\mathrm{r}}$ & This study \\
\hline
\end{tabular}

${ }^{a}$ The name of strain used for the purpose of this study is given in brackets. Strains obtained in this study are deposited in the publicly accessible IBB PAS laboratory culture collection. Strain IBB477 is deposited in the Polish Collection of Microorganisms-PCM culture collection no. 2853 
Table 2 Primer pairs used for the analysis of plasmid-free derivatives of IBB477 and for construction of IBB477 deletion mutants

\begin{tabular}{|c|c|}
\hline Plasmid/mutant name & Primers $^{\mathrm{a}}$ \\
\hline \multirow[t]{2}{*}{$\mathrm{pIBB} 477 \mathrm{a}$} & p477a_F TGCAAATCCTACACATGACACAAT \\
\hline & p477a_R GCTTCAACGGCTTCTCCTAA \\
\hline \multirow[t]{4}{*}{ pIBB477b } & p477b1_F GCGGAGCCAAGAGAAGGTA ${ }^{\mathrm{b}}$ \\
\hline & p477b1_R CTTAAAAGCATCAAACAAACT \\
\hline & p477b2_F CAGCCAAGTAATCGTCGCATAA \\
\hline & p477b2_R CGAATCCATCAAAGTTTAGGGTAT \\
\hline \multirow[t]{4}{*}{ pIBB477c } & p477c1_F GGCAAACAATCCTGAAAAGTA ${ }^{\mathrm{b}}$ \\
\hline & p477c1_R GACATCAGCTTGCCCTACTCG \\
\hline & p477c2_F TTGGAGATTATCGCTGGTGAACTA \\
\hline & p477c2_R TCTAACCGCCAAACAACGAT \\
\hline \multirow[t]{4}{*}{ pIBB477d } & p477d1_F TTATGACAGGGAGGCGTTAG ${ }^{\mathrm{b}}$ \\
\hline & p477d1_R CCGACCAATCGATAGCATAG \\
\hline & p477d2_F CGCAGGAAGAAGTCCAAACC \\
\hline & p477d2_R AGATACCTGCACGCTGTGTC \\
\hline \multirow[t]{2}{*}{ pIBB477e } & p477e_F TCCGCTATGTCCATAATCCG ${ }^{\mathrm{b}}$ \\
\hline & p477e_R ATTTACGCCACCACTCTAGG \\
\hline \multirow[t]{4}{*}{$\Delta 14140$} & 14140-u_F AACCTCTATCGCTCCCTATG \\
\hline & 14140-u_R CGAATT-CAATGGTCACTTCCTGATTAGC (EcoRI) \\
\hline & 14140-d_F CGAA-TTCACGCTTCCCAATTAGTCAAC (EcoRI) \\
\hline & 14140-d_R GGCCATCTTGATTGTTAGGG \\
\hline \multirow[t]{4}{*}{$\Delta \mathrm{prtP}$} & prtP-u_F AACAGTCACATTGGCGAAAG \\
\hline & prtP-u_R CGAA-TTCAGCGGAAGCAACTGTGG (EcoRI) \\
\hline & prtP-d_F CGAATT-CCGACATTGCTGACACATTG (EcoRI) \\
\hline & prtP-d_R GATACGCTGCTGCCCTAAAC \\
\hline
\end{tabular}

${ }^{\text {a }}$ Restriction sites are indicated in bold letters

${ }^{\mathrm{b}}$ Primer pairs used for multiplex PCR manufacturer's instructions (Fermentas, St. Leon-Rot, Germany). DNA was analysed by electrophoresis on agarose gels, which were subsequently photographed under UV light.

\section{Construction of deletion mutants}

Mutants were created using an integration-excision system based on the thermosensitive plasmid pGhost9 (Maguin et al. 1996) with added 3' terminal thymidine to both ends after EcoRV digestion, as previously described (RadziwillBienkowska et al. 2016). The mutants and primer pairs used for their construction are presented in Tables 1 and 2, respectively.

\section{Adhesion tests to polystyrene, mucin and fibronectin}

Adhesive properties of bacterial cells were tested on bare 96well polystyrene microtiter plates (cat. no. 167008, Thermo Fisher Scientific, Nunc A/S, Waltham, MA, USA) as well as microtiter plates coated with type III mucin from porcine stomach (PGM) (cat. no. M1778, Sigma-Aldrich, St. Louis, MO, USA) $\left[10 \mathrm{mg} \mathrm{ml}^{-1}\right]$ or fibronectin from human plasma
(FN) (cat. no. F2006, Sigma-Aldrich, St. Louis, MO, USA) $\left[20 \mu \mathrm{g} \mathrm{ml}^{-1}\right]$ dissolved in phosphate-buffered saline (PBS), $\mathrm{pH}=7.4$ (BioShop Canada Inc., Burlington, Ontario, Canada), using the technique described for the IBB477 strain and its deletion mutants in chromosomal genes (RadziwillBienkowska et al. 2016). Briefly, bacterial suspensions $\left(\mathrm{OD}_{600 \mathrm{~nm}}=1\right)$ were incubated in bare (polystyrene $\left.(\mathrm{PS})\right)$ or coated plates (PS + PGM, PS + FN) for $3 \mathrm{~h}$ at $30^{\circ} \mathrm{C}$, unbound bacteria were washed away with water, and adherent bacteria were stained with crystal violet. Each microtiter plate included the control strains: the wild-type IBB477 strain, which is highly adhesive to PS, PS + PGM and PS + FN (Le et al. 2011, 2012; Radziwill-Bienkowska et al. 2014, 2016), L. lactis MG1820, which has low adhesion to PS and PS + PGM (Dague et al. 2010; Le et al. 2011, 2012; RadziwillBienkowska et al. 2016), and L. lactis IL1403, which has low adhesion to PS, PS + PGM and PS + FN (RadziwillBienkowska et al. 2016), as well as blank wells with PBS. The adhesion was expressed as the optical density $\left(\mathrm{OD}_{583 \mathrm{~nm}}\right)$ of stained cells. The average value of at least six measurements from three independent experiments was calculated after rejecting extreme results. 


\section{Cell line and culture conditions}

The HT29-MTX mucus-secreting subpopulation of human colon carcinoma cell line HT29 was kindly provided to Muriel Thomas (Micalis, INRA, Jouy-en-Josas, France) by Dr. Thécla Lesuffleur (INSERM UMR S 938, Paris, France) (Lesuffleur et al. 1990). The HT29-MTX cells were routinely grown in Dulbecco's modified Eagle's minimal essential medium (DMEM) containing phenol red and $4.5 \mathrm{~g} \mathrm{l}^{-1}$ glucose (Lonza, Verviers, Belgium), supplemented with: 10\% (v/v) heat-inactivated FBS (Lonza, Verviers, Belgium), $1 \%(v / v)$ L-glutamine $200 \mathrm{mM}$ (Lonza, Verviers, Belgium) and 1\% ( $v /$ v) penicillin-streptomycin mixture $\left(10,000 \mathrm{U} \mathrm{ml}^{-1}\right.$ and $10,000 \mu \mathrm{g} \mathrm{ml}^{-1}$, respectively) (Lonza, Verviers, Belgium). The cells were seeded at a concentration of $2.5 \times 10^{4}$ cells $\mathrm{cm}^{-2}$ in six-well tissue culture plates (Thermo Fisher Scientific, Nunc A/S, Waltham, MA USA) or on glass coverslips placed in 24-well tissue culture plates (Thermo Fisher Scientific, Nunc A/S, Waltham, MA USA) for adhesion experiments and for fluorescent staining experiments, respectively. Two days before the experiments, antibiotics were no longer added to the cell culture medium. HT29-MTX cells were used between passages 27 and 46. To ensure full differentiation of cells, experiments were carried out 20 to 22 days post seeding. The cells were maintained at $37{ }^{\circ} \mathrm{C}$ in a humidified atmosphere with $10 \% \mathrm{CO}_{2}$, and the culture medium was changed daily.

\section{Adhesion test to HT29-MTX cells}

Adhesion experiments to the HT29-MTX cell line were performed according to the method described previously by Turpin et al. (2012), with some modifications. Bacterial cells from 12-h precultures were used to inoculate cell culture medium with reduced FBS concentration $[2 \%(v / v)]$ at a starting $\mathrm{OD}_{600 \mathrm{~nm}}=0.05$. After an 8-h adaptation phase, bacteria were washed, suspended in fresh culture medium with $2 \%$ FBS and diluted to obtain bacterial cell concentration of 3-4 $\times 10^{7} \mathrm{CFU}$ $\mathrm{ml}^{-1}$. HT29-MTX cells were gently washed twice with PBS, $\mathrm{pH}=7.5$ (Lonza, Verviers, Belgium), and $2 \mathrm{ml}$ of bacterial suspensions was added to each well, resulting in bacterial cellto-epithelial cell ratio (MOI) of 10:1. The bacterial and epithelial cells were co-incubated for $2 \mathrm{~h}$ at $37^{\circ} \mathrm{C}$ in a humidified atmosphere with $10 \% \mathrm{CO}_{2}$. After incubation, HT29-MTX cells were washed twice with PBS to remove unbound bacteria, scraped with $0.1 \%(v / v)$ Triton X-100 (Sigma-Aldrich, St. Louis, MO, USA), passed five times through a 21-gauge needle and incubated for $30 \mathrm{~min}$ at room temperature. Using the plating method, the number of viable bacterial cells was determined in the cell pellet (adherent bacterial cells) and in the bacterial suspension after incubation in empty wells (control input). Results were expressed as the percentage of adherent bacterial cells with respect to the amount of bacteria added (control input). At least three independent experiments were performed, and for each well, at least three serial dilutions in duplicate were carried out.

\section{Fluorescent staining of mucus secreted by HT29-MTX cells and adherent bacteria}

The adherent bacteria and mucus secreted by HT29-MTX cells were stained after performing an adhesion test. Bacterial suspensions were prepared and co-incubated with HT29-MTX cells as described earlier. The amount of bacteria added to each well was adjusted to $0.5 \mathrm{ml}$, as for staining purposes, HT29-MTX cells were grown on glass coverslips placed in 24-well tissue culture plates. After co-incubation, HT29-MTX cells were washed twice with $\mathrm{PBS}, \mathrm{pH}=7.5$ (Lonza, Verviers, Belgium), to remove unbound bacteria, fixed with $4 \%$ paraformaldehyde (PFA) (Thermo Fisher Scientific, Fisher Scientific, Waltham, MA USA) for $15 \mathrm{~min}$ at room temperature and washed three times with cold PBS. First, the adherent bacteria were stained using fluorescent in situ hybridisation (FISH), by the technique adapted from Rochet et al. (2004), with EUB 338 probe (5'-GCTG CCTCCCGTAGGAGT-3') specific for the domain Bacteria (Amann et al. 1990) and labelled with fluorescein isothiocyanate (FITC) (Qbiogene, Evry, France). Glass coverslips with fixed cells were incubated with $50 \mu \mathrm{l}$ of hybridisation solution (900 mM NaCl; 20 mM Tris- $\mathrm{HCl}, \mathrm{pH} \mathrm{8.0;0.01 \%} \mathrm{sodium}$ dodecyl sulphate (SDS); $30 \%$ formamide) containing $6 \mathrm{ng} \mu \mathrm{l}^{-1}$ of fluorescent probe for $16 \mathrm{~h}$ at $35^{\circ} \mathrm{C}$ in humidified atmosphere. Then, the coverslips were washed three times for $10 \mathrm{~min}$ at $37^{\circ} \mathrm{C}$ with washing solution (64 mM NaCl; $20 \mathrm{mM}$ Tris- $\mathrm{HCl}, \mathrm{pH} 8.0 ; 0.01 \%$ SDS) and three times with cold PBS. Next, immunofluorescence staining of mucus produced by HT29-MTX cells was performed using the anti-MUC5AC antibody as MUC5AC is the major gel-forming mucin in this in vitro model (Lesuffleur et al. 1993). Glass coverslips after FISH staining were blocked for $1 \mathrm{~h}$ at room temperature with $3 \%(w / v)$ bovine serum albumin (BSA) (Sigma-Aldrich, St. Louis, MO, USA) in PBS. Then, coverslips were incubated in a 1:100 dilution of rabbit anti-MUC5AC (H-160) primary antibody (Santa Cruz Biotechnology, Heidelberg, Germany) for $1 \mathrm{~h}$ at room temperature. Indirect fluorescence was carried out for $1 \mathrm{~h}$ at room temperature using 1:400 goat antirabbit antibody conjugated with Alexa Fluor 647 (Thermo Fisher Scientific, Invitrogen, Waltham, MA USA). After each incubation with antibody, HT29-MTX cells were washed four times with cold PBS for $10 \mathrm{~min}$. Stained glass coverslips were mounted on Superfrost microscope slides (Thermo Fisher Scientific, Thermo Scientific, Waltham, MA USA) using ProLong Gold antifade reagent (cat. no. P36930, Thermo Fisher Scientific, Life Technologies, Waltham, MA USA). For each bacterial strain, at least two independent experiments 
were performed in duplicate. Controls included no bacteria, no HT29-MTX cells and no primary antibody.

\section{Confocal microscopy}

Stained HT29-MTX cells with adherent bacteria were examined using a motorised stage on the Leica TCS SP8 AOBS inverted confocal microscope (Leica Microsystems, Mannheim, Germany) at the INRA MIMA2 platform (http:// www.jouy.inra.fr/mima2). Observations were performed using $\times 63 / 1.40$ oil immersion objective. FITC was excited at $488 \mathrm{~nm}$ using an argon laser [output power at 30\%, acoustooptic tunable filter (AOTF) ca. 5\%] and was detected between 500 and $550 \mathrm{~nm}$. Simultaneously, Alexa Fluor 647 was excited at $633 \mathrm{~nm}$ using $\mathrm{He} / \mathrm{Ne}$ laser (AOTF ca. 0.7\%) and the emitted fluorescence was recorded from 638 to $790 \mathrm{~nm}$. Signals were recorded with hybrid detectors (HyD) in standard mode with $100 \%$ digital gain. Single 3D acquisitions as well as mosaics $(3 \times 3$, with automated merging and stitching of 10-20\%) were acquired at a scan speed of $600 \mathrm{~Hz}$ in bidirectional mode with scanning zoom 1 , an image resolution of $1024 \times 1024$ pixels, a line average of 2 and a $z$-step between each $x y$ image for a $z$-stack of $0.3 \mu \mathrm{m}$. The images were analysed, and graphical representations were prepared using the IMARIS 7.7.2 software (Bitplane, Zurich, Switzerland).

\section{Digestive stress test}

Resistance of bacterial strains to acid and bile salts was assessed using the method adapted from Kechaou et al. (2013). Bacteria from overnight cultures were washed twice with PBS, $\mathrm{pH}=7.5$ (Lonza, Verviers, Belgium), and diluted to $\mathrm{OD}_{600 \mathrm{~nm}}=0.5$ in $1 \mathrm{ml}$ of PBS, $\mathrm{pH}=7.5$ (control); $\mathrm{PBS}, \mathrm{pH}=3$ (acid stress); and PBS, $\mathrm{pH}=7.5$, containing $3 \mathrm{~g} \mathrm{l}^{-1}$ of two bile salts: sodium cholate and sodium deoxycholate (SigmaAldrich, St. Louis, MO, USA) (bile salt stress). After incubation for $1 \mathrm{~h}$ at $37^{\circ} \mathrm{C}$, bacterial cells were washed with PBS and suspended in M17-glucose $(0.5 \% \mathrm{w} / \mathrm{v})$ medium. For each strain and each condition, four 2fold serial dilutions were prepared in duplicate on a sterile 384-well microtiter plate (Greiner Bio-One GmbH, Frickenhausen, Germany) starting from $\mathrm{OD}_{600 \mathrm{~nm}}=0.025$. Growth of bacteria at $37{ }^{\circ} \mathrm{C}$ was monitored every $15 \mathrm{~min}$ for $28 \mathrm{~h}$ by measuring the $\mathrm{OD}_{600} \mathrm{~nm}$ with the Infinite M200 Pro plate reader (Tecan, Maennedorf, Switzerland). The resistance of bacterial strains to digestive stress was determined by measuring the growth delay (i.e. delay in time needed to reach mid-exponential phase) between stressed and non-stressed cultures. For each strain and each condition, four growth delays corresponding to the four dilutions on the microtiter plate were averaged.

\section{In vivo approach}

Conventional C57Bl/6 mice (males, 6 weeks of age; Janvier Labs, Le Genest Saint Isle, France) were maintained under normal husbandry conditions in the animal facilities of the INRA IERP Unit (Jouy-en-Josas, France). All animal experiments began after 1-week acclimation and were performed according to the European Community rules of animal care and with authorisation 12-164 of the French Veterinary Services. Overnight cultures of bacteria, performed in $200 \mathrm{ml}$ of M17-glucose $(0.5 \% w / v)$ medium supplemented with antibiotics (Nal and Tet), were washed three times with PBS, $\mathrm{pH}=7.5$ (Lonza, Verviers, Belgium) and suspended in $1.5 \mathrm{ml}$ of PBS to a final concentration of $\mathrm{OD}_{600 \mathrm{~nm}}=100$. Mice $(n=6)$ were intragastrically administered with $100 \mu \mathrm{l}$ of bacterial suspensions, i.e. $3 \times 10^{9} \mathrm{CFU}$ per mouse (verified by plating). In order to investigate the persistence of bacteria in the GIT, faeces were collected for plating just before the gavage (control) and after 4, 8, 48 and $72 \mathrm{~h}$. During that time, the bedding was changed daily. To determine the localisation of bacteria in the GIT, $72 \mathrm{~h}$ after first gavage, mice were administered again with bacteria $\left(2 \times 10^{9} \mathrm{CFU}\right.$ per mouse $)$ and sacrificed by cervical dislocation $24 \mathrm{~h}$ later. After sacrifice, contents of stomach, ileum, caecum and colon were collected for plating. Collected faeces and intestinal contents were suspended in PBS $(100 \mu \mathrm{l}$ per $10 \mathrm{mg})$, and for each sample, four serial dilutions were plated on appropriate selective plates. The authenticity of the counted colonies (one colony for each strain for each time point and each intestinal region) was verified by colony PCR with two primer sets: $68 \mathrm{~F}$ (5'-GATGAAGATTGGTG CTTGCA- $3^{\prime}$ ) and 1406R (5'-ACGGGCGGTGTGTRC$3^{\prime}$ ) specific for L. lactis subsp. cremoris (Salama et al. 1991) and Mub-outF (5'-TGCTTACGCTCATATCCTTC$\left.3^{\prime}\right)$ and Mub-outR (5'-CATTTGCTTGCTCAGAGTTC3') amplifying AJ89_12755 gene (mub gene), which was shown to be longer in the IBB477 strain than that found in other L. lactis subsp. cremoris genomes (Radziwill-Bienkowska et al. 2014).

\section{Statistical analysis}

Statistical analysis was performed using GraphPad Prism software (GraphPad Software, Inc., San Diego, CA). Results from adhesion tests to mucin, fibronectin and HT29-MTX cells were expressed as means \pm SD and analysed by Welch's $t$ test. Differences were considered statistically significant when $p$ value was $<0.05$. In vivo data were presented as 25 th to 75 th percentile boxes with median line in the middle and all individual values marked. 


\section{Results}

Influence of plasmids on $L$. lactis IBB477 adhesion to bare polystyrene

To elucidate the role of plasmids in adhesion of L. lactis IBB477 strain, a set of plasmid-free derivatives was obtained using a plasmid-curing method based on passages and prolonged growth without any toxic compounds to minimise spontaneous mutations. The absence of plasmids in derivatives was confirmed by PCR analyses and by comparing plasmid profiles after agarose gel electrophoresis of purified plasmids and plasmid DNA digested with restriction enzymes (data not shown). The obtained derivatives include those lacking single plasmids: pIBB477a, pIBB477b, pIBB477c and pIBB477d; two plasmids: pIBB477a and b, pIBB477a and c, or pIBB477a and d, as well as one derivative lacking three plasmids pIBB477a, $\mathrm{b}$ and $\mathrm{c}$ (Table 1). The adhesive properties of IBB477 derivatives were analysed using adhesion tests on bare PS (Fig. 1). A significant decrease in adhesion to bare PS was observed for all derivatives without plasmid pIBB477b. A decrease in adhesion was also observed for derivative lacking single plasmid pIBB477a; however, results were less reproducible, and the effect was not visible for derivatives lacking two plasmids pIBB477a and c or pIBB477a and $\mathrm{d}$. The lowest adhesion level among plasmid-free derivatives was measured for all derivatives lacking both plasmids pIBB477a and b. Derivatives without single plasmids pIBB477c or $\mathrm{d}$ had similar adhesion level as the wild-type IBB477 strain. These results suggest that one or more genes that are localised on plasmid pIBB $477 \mathrm{~b}$ play a role in adhesion of the IBB477 strain.

\section{Adhesion of deletion mutants in putative adhesion genes localised on plasmid pIBB477b to bare, mucin- and fibronectin-coated PS}

Based on our recently published results on IBB477 (Radziwill-Bienkowska et al. 2016), only two proteins encoded by genes located on the pIBB477b plasmid were

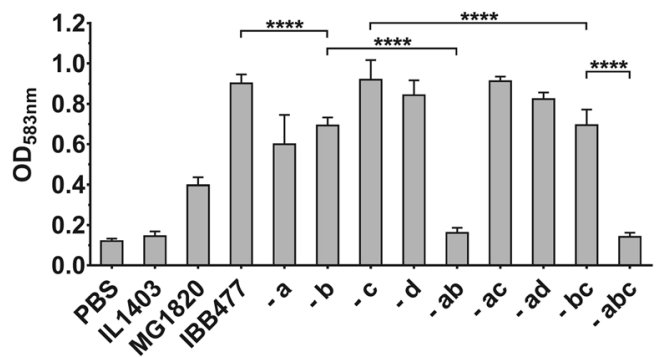

Fig. 1 Adhesion of IBB477 plasmid-free derivatives to bare polystyrene (PS). Adhesion is expressed as optical density $\left(\mathrm{OD}_{583 \mathrm{~nm}}\right)$ of stained cells. Means \pm standard deviations from three independent experiments are shown. The $p$ values were calculated using Welch's $t$ test $\left(* * * * p\right.$ value $\left.<\mathrm{e}^{-4}\right)$ found as putative adhesins according to their extracellular or cell wall localisation: the AJ89 14230 gene coding for peptidase S8 with homology to L. lactis PrtP protein and the gene with locus tag AJ89 14140 annotated as a hypothetical protein. These two genes were thus selected for deletion and functional analysis. The adhesive properties of IBB477 deletion mutants, $\Delta$ prtP and $\Delta 14140$, were tested on bare polystyrene plates (PS) as well as on plates coated with mucin $(\mathrm{PS}+\mathrm{PGM})$ and fibronectin $(\mathrm{PS}+\mathrm{FN})$ in comparison with the wild-type strain (Fig. 2). Adhesion was expressed as the optical density $\left(\mathrm{OD}_{583 \mathrm{~nm}}\right)$ of stained cells. One of the IBB477 plasmidic deletion mutants ( $\Delta$ prtP) in gene AJ89_14230 adhered significantly less than the wild-type IBB477 strain, with $p$ value $<\mathrm{e}^{-4}$ (95\% CI $=-0.44$ to -0.37$), p$ value $<\mathrm{e}^{-4}(95 \%$ $\mathrm{CI}=-0.18$ to -0.14$)$ and $p$ value $<\mathrm{e}^{-4}(95 \% \mathrm{CI}=-0.28$ to $-0.22)$ to PS, PS + PGM and PS + FN, respectively. $\Delta$ prtP showed ca. $55 \%$ of adherence compared with IBB477 strain in all three cases. Deletion of AJ89_14140 gene did not significantly change the adhesion level of the corresponding deletion mutant to any of tested surfaces compared to the wild-type strain. Despite many efforts to construct the strain complementing $\Delta$ prtP, all attempts failed, probably owing to the length (more than $6 \mathrm{~kb}$ ) of the nucleotide sequence of the AJ89_14230 gene. However, in our study, several independently constructed deletion mutants in this gene located on pIBB $477 \mathrm{~b}$ plasmid were analysed and presented similar levels of adhesion to each tested surface (data not shown).

\section{Adhesion to the mucus-secreting cell line of the IBB477 strain and its deletion mutant $(\Delta$ prtP)}

To further investigate the role of the AJ89_14230 gene in adhesive behaviour of IBB477 strain, adhesion test to the mucus-secreting HT29-MTX cell line was performed for the wild-type IBB477 vs. its $\Delta$ prtP mutant. The adaptation phase of bacteria in cell culture medium was set for $8 \mathrm{~h}$ as the

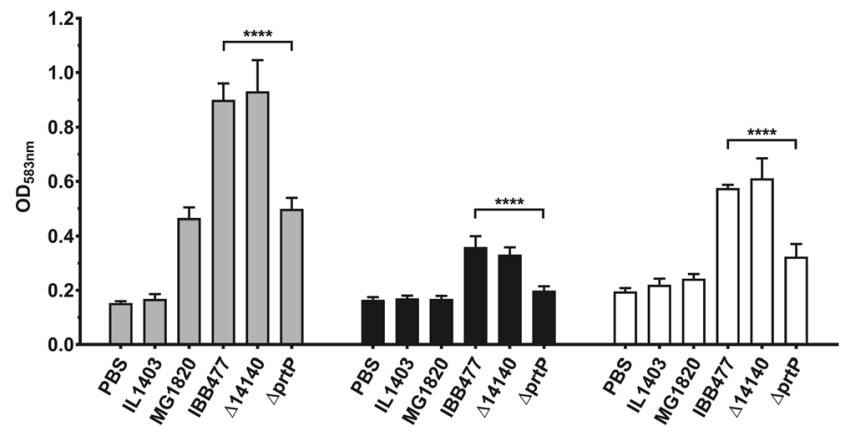

Fig. 2 Adhesion of IBB477 and its two deletion mutants in putative adhesion genes localised on plasmid pIBB477b to bare polystyrene (PS) (grey bars), mucin-coated polystyrene (PS + PGM) (black bars) and fibronectin-coated polystyrene (PS + FN) (white bars). Adhesion is expressed as optical density $\left(\mathrm{OD}_{583 \mathrm{~nm}}\right)$ of stained cells. Means \pm standard deviations from three independent experiments are shown. The $p$ values were calculated using Welch's $t$ test $\left(* * * * p\right.$ value $<\mathrm{e}^{-4}$ ) 
maximal $\mathrm{OD}_{600 \mathrm{~nm}}$ for both strains was observed for $7.5 \mathrm{~h}$ and as after $9 \mathrm{~h}$ of incubation, $\mathrm{OD}_{600 \mathrm{~nm}}$ and number of viable cells began to decrease (data not shown). Susceptibility of tested strains to $0.1 \%(v / v)$ Triton X-100 was verified, and no significant differences in survival rates were observed in comparison with non-treated bacteria (data not shown). Based on CFU counting, the percentage of adherent bacterial cells to HT29MTX cells was determined for IBB477 strain and its deletion mutant ( $\Delta$ prtP) (Fig. 3). The level of adhesion obtained for IBB477 (18\%) was significantly higher than for $\Delta$ prtP (11\%) with $p$ value $<\mathrm{e}^{-2}(95 \% \mathrm{CI}=3.87$ to 10.8$)$.

To visualise the interactions between bacteria and HT29MTX cells, stained cells and bacteria were examined under confocal microscope for IBB477 and its deletion mutant $(\Delta$ prtP). Representative images are shown in Fig. $4 \mathrm{a}, \mathrm{b}$. First, mucus stained with MUC5AC antibody did not form a uniform layer over the cell surface, but rather a patchy structure (Fig. 4a, b), and the maximal thickness of patches was $5 \mu \mathrm{m}$. Then, for both strains, it was observed that, in general, bacterial cells formed clusters that were embedded in mucus and sparsely distributed along the sample. The density of bacterial clusters was higher for IBB477 strain than for $\Delta$ prtP mutant. It was noted that for both strains, some bacterial cells were not localised in mucus but rather in direct contact with the apical side of HT29-MTX cells.

\section{Transit of the IBB477 strain and its deletion mutant $(\Delta$ prtP) in conventional C57Bl/6 mice}

In order to investigate the ability to persist in the GIT of conventional rodents and observe the potential differences in the transit between IBB477 and its deletion mutant $(\Delta$ prtP), in relation to their different in vitro adhesive phenotypes, a C57Bl/6 mice model was used.

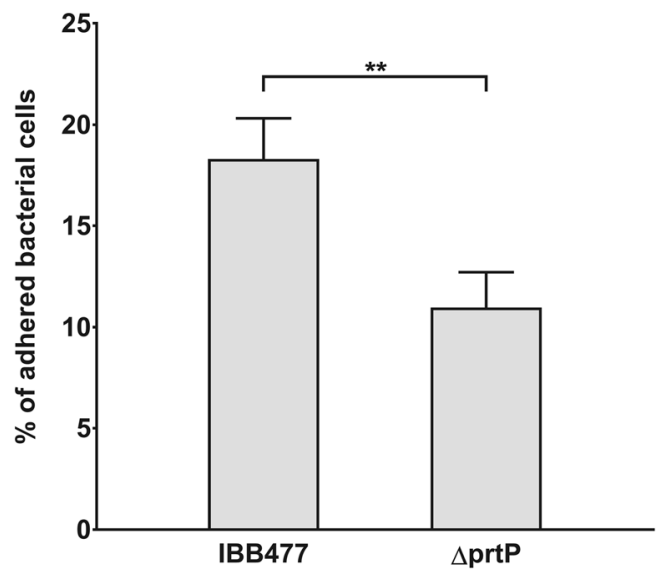

Fig. 3 Adhesion of IBB477 and its deletion mutant in AJ89_14230 gene ( $\Delta$ prtP) to mucus-secreting HT29-MTX cells. Adhesion is expressed as percentage of adherent bacterial cells with respect to the amount of bacteria added. Means \pm standard deviations from three independent experiments are shown. The $p$ values were calculated using Welch's $t$ test $(* * p$ value $<\mathrm{e}^{-2}$ )
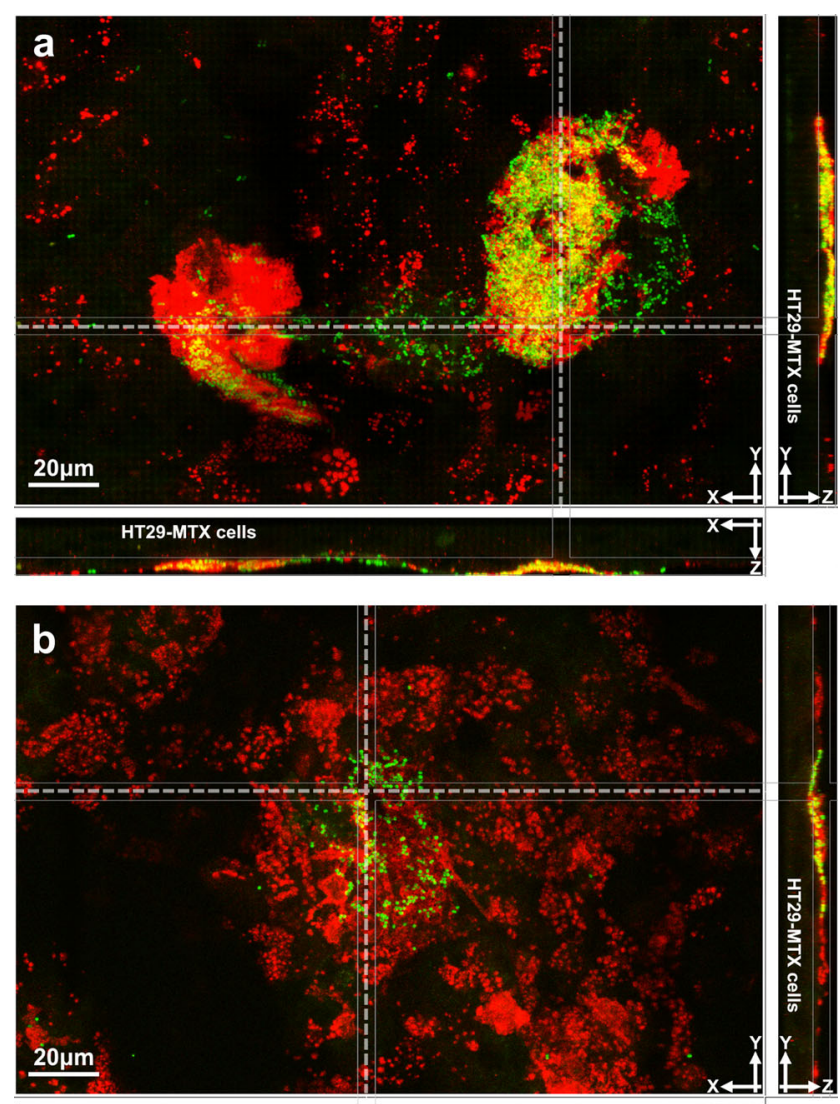

HT29-MTX cells

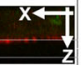

Fig. 4 Visualisation of interactions between bacteria (in green, FISH probe Eub338) and mucus (in red, anti-MUC5AC antibody) secreted by HT29-MTX cells with confocal microscopy. Representative confocal $z$-stack images of HT29-MTX cells, mucus and bacterial strains: IBB477 (a) and its $\Delta$ prtP mutant (b) after 2-h adhesion are displayed in easy $3 \mathrm{D}$ section view with large z-sections $(x, y)$ at the level of mucus and orthogonal $x(y, z)$ and $y(x, z)$ sections on the right and on the bottom, respectively. Yellow colour indicates bacteria that are embedded in mucus. Positions of orthogonal sections are indicated on z-sections with dashed lines. Localisation of HT29-MTX cells (slight autofluorescence in green) is marked on orthogonal sections. For all sections, the extended view with signal gathered from thickness of $5 \mu \mathrm{m}$ was selected. The images were prepared using the IMARIS software (Color figure online)

As a first step, an in vitro digestive stress test was performed to verify whether deletion of AJ89_14230 gene did not change the resistance properties of the $\Delta$ prtP mutant in comparison with the wild-type IBB477 strain. Bacteria were subjected to acid $(\mathrm{pH}=3)$ and bile salts to mimic the passage through the GIT. Data were then analysed according to Kechaou et al. (2013). No significant differences in the growth delays between tested strains were observed (acid stress $5.9 \mathrm{~h} \pm 0.6$ vs. $6.5 \mathrm{~h} \pm 0.7$ and bile salt stress $8.5 \mathrm{~h} \pm 1.3$ vs. $8.5 \mathrm{~h} \pm 1.6$ for IBB477 vs. $\Delta$ prtP), indicating similar levels of resistance to digestive stresses for both strains.

Next, persistence of IBB477 and its deletion mutant $(\Delta \mathrm{prtP})$ in the GIT of conventional C57Bl/6 mice after single oral administration was determined (Fig. 5). For both strains, the number of viable bacterial cells in faeces of mice 


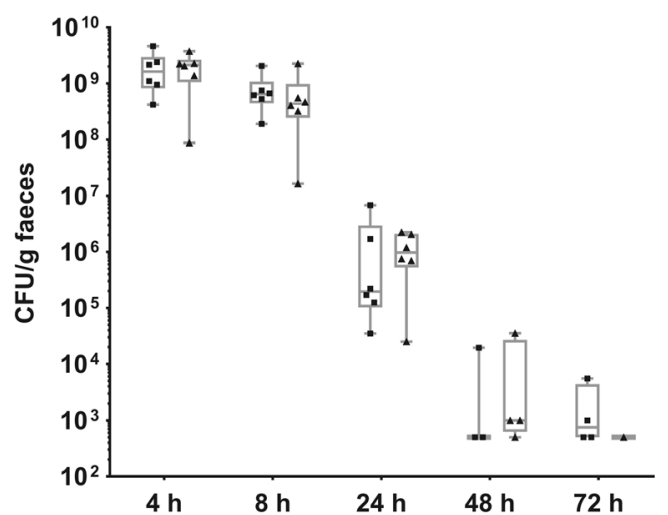

Fig. 5 Persistence of IBB477 (squares) and its deletion mutant in AJ89 14230 gene ( $\Delta$ prtP) (triangles) in the GIT of conventional C57B1/6 mice after single oral administration. Bacterial counts in faeces of mice $(n=6)$ are presented as 25 th to 75 th percentile boxes with median line in the middle and all individual values marked

progressively decreased between 4 and $48 \mathrm{~h}$ after gavage (from ca. $10^{9}$ to $10^{4} \mathrm{CFU} / \mathrm{g}$ faeces). At $72 \mathrm{~h}$ after administration, IBB477 was still detected at $10^{3} \mathrm{CFU} / \mathrm{g}$ faeces in four mice, but $\Delta$ prtP was detected in the faeces of only one animal ( $n=6$ mice in both cases).

Finally, the amounts of IBB477 strain and its $\Delta$ prtP mutant in different parts of the GIT of conventional C57Bl/6 mice $24 \mathrm{~h}$ after gavage were investigated (Fig. 6). Both strains were detected in all intestinal regions at similar levels with the highest amount found in the colon and caecum (ca. $10^{6} \mathrm{CFU} / \mathrm{g}$ luminal content).

\section{Discussion}

In the present work, adhesion and persistence of L. lactis subsp. cremoris IBB477 strain were analysed by in vitro and in vivo approaches, respectively. In our previous study on adhesion of IBB477, we demonstrated that the chromosomal

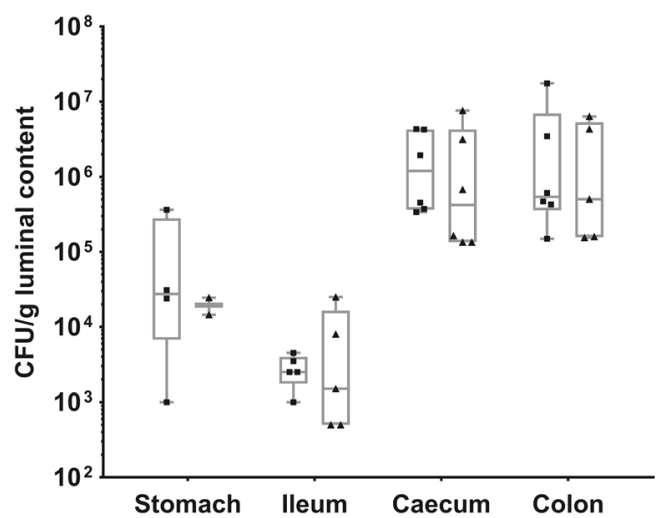

Fig. 6 Amount of IBB477 (squares) and its deletion mutant in AJ89 14230 gene $(\Delta \mathrm{prtP})$ (triangles) in the GIT (stomach, ileum, caecum and colon) of conventional C57Bl/6 mice $24 \mathrm{~h}$ after gavage. Bacterial counts in luminal contents of mice $(n=6)$ are presented as 25 th to 75 th percentile boxes with median line in the middle and all individual values marked gene encoding the AJ89 07570 protein containing DUF285, C-term_anchor (recently reclassified as MucBP (PF06458) domain) and four Big_3 domains is involved in adhesion to abiotic surfaces as well as mucins (Radziwill-Bienkowska et al. 2016). Here, we focus on the role of molecular factors localised on plasmids in the adhesive properties of the IBB477 strain and their impact on its persistence in the GIT.

Using a plasmid-curing method, a set of plasmid-free derivatives of IBB477 was obtained and analysed. The frequency of loss of plasmids differed for each plasmid (data not shown). Adhesion tests on bare PS plates revealed that two plasmids, pIBB477a and $b$, are involved in adhesion of the IBB477 strain. Whereas for all obtained derivatives without plasmid pIBB477b (-b, -ab, -bc and -abc), the level of adhesion was lower than that for the wild-type IBB477 strain, the role of plasmid pIBB477a in adhesion is less straightforward. For derivatives that only lost pIBB477a plasmid, adhesion was lowered but the variation level was high. For derivatives without two plasmids -ac and -ad, no significant changes were observed. However, the simultaneous loss of pIBB477a and pIBB477b plasmids ( $-\mathrm{ab}$ and -abc derivatives) resulted in a very pronounced loss of adhesive properties of IBB477 strain to bare PS (similar level of adhesion as for IL1403 control strain). This observation strongly suggests that there is an interaction between molecular factors encoded by both plasmids that plays a role in adhesion of the IBB477 strain. Further analysis is required to confirm this hypothesis. A similar hypothesis claiming that the open reading frames carried by different plasmids or located on plasmids and on the chromosome in lactococci form functional biological systems have been proposed (Górecki et al. 2011). Notably, the role of multiple cell surface proteins in adhesive properties was previously reported for other LAB strains such as Lactobacillus acidophilus NCFM and Lactobacillus gasseri SBT2055 (Buck et al. 2005; Arai et al. 2016). In the present study, we decided to focus on further investigation of the role of plasmid IBB477b, owing to its major role in the adhesive phenotype of the IBB477 strain.

On the recently published list of putative adhesins of IBB477 strain (Radziwill-Bienkowska et al. 2016), there are only two proteins encoded by genes localised on plasmid pIBB477b, i.e. the hypothetical protein of extracellular localisation (AJ89_14140) and the cell wall-attached peptidase S8 (AJ89_14230), which is homologous to the L. lactis PrtP protein. Deletion mutants in corresponding genes were created and analysed in terms of adhesion to bare microtiter plates or plates coated with mucin or fibronectin. AJ89_14230 protein was found to mediate adhesion to bare, mucin- and fibronectin-coated PS. Cell surface-associated macromolecules are considered to play an important role in the adhesion of LAB to the GIT (Sengupta et al. 2013). Notably, AJ89_14230 protein of IBB477 has high sequence similarity to proteinase PrtP from the L. lactis subsp. cremoris $\mathrm{Wg} 2$ 
strain (EMBL accession number M24767; Blastp result 100\% query coverage and $94 \%$ identity), which was shown to enhance cell surface hydrophobicity and mediate adhesion to solid surfaces such as glass, polytetrafluorethylene (PTFE) and octadecanethiol (ODT) self-assembled monolayer (SAM) when introduced in the L. lactis subsp. cremoris MG1363 strain (Habimana et al. 2007; Bulard et al. 2012).

The IBB477 strain and its deletion mutant in the AJ89 14230 gene $(\Delta$ prtP) were further investigated in vitro using the mucus-secreting HT29-MTX cell line. As expected, the percentage of adherent bacterial cells was significantly lower for $\Delta$ prtP than for IBB477. Confocal images showed that both tested strains, in general, formed cell clusters embedded in mucus. However, the density of those clusters varied depending on the strain (i.e. a higher amount of aggregated bacterial cells was observed for IBB477 than for $\Delta$ prtP mutant). Dense clusters of bacteria interacting with mucus secreted by HT29-MTX cells have previously been observed by scanning electron microscopy (SEM) for adhering $L b$. acidophilus BG2FO4 strain (Coconnier et al. 1992). It was also reported that Helicobacter pylori forms discrete foci or clusters throughout the mucus layer and close to the epithelium of a subpopulation of HT29-MTX cells (HT29-MTX-E12 cell line), when investigated by confocal microscopy (Dolan et al. 2012). Therefore, the ability to form dense clusters in mucus might be a characteristic feature of strains that are capable of colonising the mucus layer. In this study, we also observed that some of the bacterial cells were in direct contact with the apical side of HT29-MTX cells. It is possible that they were interacting with membrane-associated mucins, most probably MUC1 or MUC3, as these two transmembrane mucins were found to be expressed at high levels in differentiated HT29-MTX cells (Lesuffleur et al. 1993). Notably, in our experiment, mucus secreted by HT29-MTX cells did not form a uniform layer over the cell surface but rather a patchy structure with thickness of up to $5 \mu \mathrm{m}$. This observation is in agreement with previous studies in which mucus patches were visualised in this in vitro model (Coïc et al. 2012; Sperandio et al. 2013; Etzold et al. 2014). However, it was also reported that mucus secreted by HT29-MTX cells formed a dense gel layer entirely covering the cell surface (Coconnier et al. 1992; Gouyer et al. 2001; Gibbins et al. 2015). These discrepancies stress the necessity of mucus examination when HT29-MTX cells are used for adhesive experiments.

To investigate the ability of IBB477 strain and its $\Delta$ prtP mutant to persist in the GIT colonised with indigenous microbiota, conventional C57B1/6 mice were used. Both the wildtype strain and its mutant were detected in faeces of mice up to $72 \mathrm{~h}$. Although at this time point, IBB477 was still present in the faeces of four mice and $\Delta$ prtP only in one (out of six), the time of transition was too short to detect statistically significant differences in their persistence. The possible explanation for lack of colonisation is that the IBB477 strain is not able to overcome the barrier that is created by the indigenous microbiota present in the GIT of C57B1/6 mice. In fact, it has been previously shown that the colonisation resistance of the resident intestinal microbiota of conventional animals often results in the elimination of introduced bacteria (van der Waaij et al. 1971; Zhang et al. 2016). Notably, persistence of some other L. lactis subsp. cremoris strains in the gut of conventional rodents was lower than for IBB477 as they were no longer detected in the faeces of animals $24-48 \mathrm{~h}$ after last administration (Schlundt et al. 1994; Brockmann et al. 1996; Watson et al. 2008). This may be related, at least to some extent, to the improved adhesive properties of IBB477 strain. Indeed, it was recently shown that the longer persistence of L. lactis CNCM I-1631 strain in conventionalised rats was partly imputable to its adherence ability to the host mucosa (Zhang et al. 2016). In addition, Watson et al. (2008) demonstrated that introduction of Listeria monocytogenes bile resistance mechanism in L. lactis NZ9000 resulted in improvement of its persistence from 24 to $72 \mathrm{~h}$. In combination with adhesive properties, other phenotypical traits could thus be involved, the utilisation of mucin-derived carbon sources, e.g. $N$-acetylglucosamine and mannose (Roy et al. 2008), being another adaptation strategy for $L$. lactis.

Apart from temporal, spatial transit of IBB477 and its $\Delta$ prtP mutant in the GIT of conventional C57Bl/6 mice was also determined. The highest amount of bacteria $24 \mathrm{~h}$ after gavage, ca. $10^{6} \mathrm{CFU} / \mathrm{g}$ luminal content, was observed in the caecum and colon. Such levels were consistent with values obtained during the kinetics study in faeces $24 \mathrm{~h}$ after gavage. Relatively high amounts of bacteria were also detected in the stomach contents of approximately half of the mice, likely due to the fact that mice are coprophages. Similar results were obtained for the L. lactis WH-C1 strain $26 \mathrm{~h}$ after administration to Swiss Albino mice (Wang et al. 2011). The same concentrations of bacteria as those observed in our study were present in the caecum and stomach, whereas for the ileum, the amount of $\mathrm{WH}-\mathrm{C} 1$ cells was around ten times higher. Notably, as for the WH-C1 strain, IBB477 was still present in the GIT of mice 3 days after administration, albeit at a lower amount $\left(10^{3} \mathrm{CFU} \mathrm{g}^{-1}\right.$ for IBB477 and $10^{4} \mathrm{CFU} \mathrm{g}^{-1}$ for $\mathrm{WH}-$ $\mathrm{C} 1)$. The differences in the levels of remaining bacteria as well as bacterial cells present in the ileum can result from specific characteristics of tested strains and/or different mouse models.

Our results suggest that LAB strains expressing peptidase with homology to L. lactis PrtP protein could possess the increased adhesive properties to the intestinal mucosa. Adhesive properties can potentially prolong the contact between exogenously applied bacteria and the host, and therefore enhance the desired beneficial effect. Previous studies showed that some lactococcal strains were either able to colonise the human GIT in subdetectable levels or able to transiently colonise the gut when introduced with food (Finegold et al. 1983; Millette et al. 2007; Lakshminarayanan et al. 2013; 
David et al. 2014). Notably, there is increasing evidence that food-borne bacteria are biologically active in the colon, and therefore, they might contribute to the functions of gut microbiota (Zhang et al. 2016). Even though the IBB477 strain is not able to colonise the GIT of conventional C57BL/6 mice, it was shown to present the adhesive properties towards mucins as well as mucus-secreting cell line. Regarding such strains that are able to bind to mucus and are transiently present in the GIT, their use as functional foods (probiotics) may require the long-term consumption.

Overall, we demonstrated that cell wall-associated peptidase S8 (PrtP), encoded by the AJ89_14230 gene localised on plasmid pIBB477b, is a key factor in adhesion of L. lactis IBB477 strain, rather than conferring it a selective advantage in the gut of conventional C57BL/6 mice. With regard to our previous results (Radziwill-Bienkowska et al. 2016), we conclude that both chromosomal and plasmid-encoded molecular factors contribute to adhesive properties of L. lactis IBB477.

Acknowledgements The 'Studies of nucleic acids and proteins - from basic to applied research' project is realised within the International $\mathrm{PhD}$ Projects Programme of the Foundation for Polish Science (MPD/2009-3/ 2). The project is co-financed by the EU Regional Development Fund. This work was also funded by European Funds Portal Innovative Economy 'Centre of medicinal product biotechnology. Package of innovative biopharmaceuticals for human and animal therapy and prophylactics' WND-POIG.01.01.02-00-007/08. The authors wish to thank Camille Aubry from Probihôte team (Micalis, INRA, Jouy-en-Josas, France) for the research advice; Alexis Canette, Jean-Marie Herry, Romain Briandet and Pierre Adenot from MIMA2 platform (INRA, Jouy-en-Josas, France) for the support with confocal microscopy imaging; and the staff of the IERP Unit (INRA, Jouy-en-Josas, France) in particular Jérôme Pottier, Marlène Hery and Charline Pontlevoy for their help during the in vivo experiments.

\section{Compliance with ethical standards}

Competing interests The authors declare that they have no conflict of interest.

Ethical statement All animal assays were performed following the European Guidelines for the Care and Use of Laboratory Animals (authorisation number of the French Veterinary Services: 12-164).

Open Access This article is distributed under the terms of the Creative Commons Attribution 4.0 International License (http:// creativecommons.org/licenses/by/4.0/), which permits unrestricted use, distribution, and reproduction in any medium, provided you give appropriate credit to the original author(s) and the source, provide a link to the Creative Commons license, and indicate if changes were made.

\section{References}

Ainsworth S, Stockdale S, Bottacini F, Mahony J, van Sinderen D (2014) The Lactococcus lactis plasmidome: much learnt, yet still lots to discover. FEMS Microbiol Rev 38:1066-1088. doi:10.1111/15746976.12074
Alpert C-A, Mater DDG, Muller M-C, Ouriet M-F, Duval-Iflah Y, Corthier G (2003) Worst-case scenarios for horizontal gene transfer from Lactococcus lactis carrying heterologous genes to Enterococcus faecalis in the digestive tract of gnotobiotic mice. Environ Biosaf Res 2:173-180. doi:10.1051/ebr:2003010

Amann RI, Binder BJ, Olson RJ, Chisholm SW, Devereux R, Stahl DA (1990) Combination of 16S rRNA-targeted oligonucleotide probes with flow cytometry for analyzing mixed microbial populations. Appl Environ Microbiol 56:1919-1925

Arai T, Obuchi S, Eguchi K, Seto Y (2016) In vitro investigation of molecules involved in Lactobacillus gasseri SBT2055 adhesion to host intestinal tract components. J Appl Microbiol 120:1658-1667. doi:10.1111/jam.13137

Bermudez-Humaran L, Kharrat P, Chatel J-M, Langella P (2011) Lactococci and lactobacilli as mucosal delivery vectors for therapeutic proteins and DNA vaccines. Microb Cell Factories 10:S4. doi:10. 1186/1475-2859-10-S1-S4

Boguslawska J, Zycka-Krzesinska J, Wilcks A, Bardowski J (2009) Intraand interspecies conjugal transfer of Tn916-like elements from Lactococcus lactis in vitro and in vivo. Appl Environ Microbiol 75:6352-6360. doi:10.1128/AEM.00470-09

Brockmann E, Jacobsen BL, Hertel C, Ludwig W, Schleifer KH (1996) Monitoring of genetically modified Lactococcus lactis in gnotobiotic and conventional rats by using antibiotic resistance markers and specific probe or primer based methods. Syst Appl Microbiol 19: 203-212. doi:10.1016/S0723-2020(96)80046-4

Buck BL, Altermann E, Svingerud T, Klaenhammer TR (2005) Functional analysis of putative adhesion factors in Lactobacillus acidophilus NCFM. Appl Environ Microbiol 71:8344-8351. doi: 10.1128/AEM.71.12.8344-8351.2005

Bulard E, Fontaine-Aupart M-P, Dubost H, Zheng W, Bellon-Fontaine M-N, Herry J-M, Bourguignon B (2012) Competition of bovine serum albumin adsorption and bacterial adhesion onto surfacegrafted ODT: in situ study by vibrational SFG and fluorescence confocal microscopy. Langmuir 28:17001-17010. doi:10.1021/ la302976u

Carter P, Bedouelle H, Winter G (1985) Improved oligonudeotide sitedirected mutagenesis using M13 vectors. Nucleic Acids Res 13: $4431-4443$

Chopin A, Chopin M-C, Moillo-Batt A, Langella P (1984) Two plasmiddetermined restriction and modification systems in Streptococcus lactis. Plasmid 11:260-263. doi:10.1016/0147-619X(84)90033-7

Coconnier MH, Klaenhammer TR, Kernéis S, Bernet MF, Servin AL (1992) Protein-mediated adhesion of Lactobacillus acidophilus BG2FO4 on human enterocyte and mucus-secreting cell lines in culture. Appl Environ Microbiol 58:2034-2039

Coïc Y-M, Baleux F, Poyraz Ö, Thibeaux R, Labruyere E, Chretien F, Sobhani I, Lazure T, Wyplosz B, Schneider G, Mulard L, Sansonetti PJ, Marteyn BS (2012) Design of a specific colonic mucus marker using a human commensal bacterium cell surface domain. J Biol Chem 287:15916-15922. doi:10.1074/jbc.M111.310003

Corthier G, Delorme C, Ehrlich SD, Renault P (1998) Use of luciferase genes as biosensors to study bacterial physiology in the digestive tract. Appl Environ Microbiol 64:2721-2722

Dague E, Le DTL, Zanna S, Marcus P, Loubière P, Mercier-Bonin M (2010) Probing in vitro interactions between Lactococcus lactis and mucins using AFM. Langmuir 26:11010-11017. doi:10.1021/ la101862n

David LA, Maurice CF, Carmody RN, Gootenberg DB, Button JE, Wolfe BE, Ling AV, Devlin AS, Varma Y, Fischbach MA, Biddinger SB, Dutton RJ, Turnbaugh PJ (2014) Diet rapidly and reproducibly alters the human gut microbiome. Nature 505:559-563. doi:10.1038/ nature 12820

de los Reyes-Gavilán CG, Suárez A, Fernández-García M, Margolles A, Gueimonde M, Ruas-Madiedo P (2011) Adhesion of bile-adapted Bifidobacterium strains to the HT29-MTX cell line is modified after 
sequential gastrointestinal challenge simulated in vitro using human gastric and duodenal juices. Res Microbiol 162:514-519. doi:10. 1016/j.resmic.2011.03.009

del Carmen S, Zurita-Turk M, Lima FA, Dos Santos JSC, Leclercq SY, Chatel J-M, Azevedo V, De Moreno Leblanc A, Miyoshi A, Leblanc JG (2013) A novel interleukin-10 DNA mucosal delivery system attenuates intestinal inflammation in a mouse model. Eur $\mathrm{J}$ Inflamm 11:641-654. doi:10.1177/1721727X1301100308

Dolan B, Naughton J, Tegtmeyer N, May FEB, Clyne M (2012) The interaction of Helicobacter pylori with the adherent mucus gel layer secreted by polarized HT29-MTX-E12 cells. PLoS One 7:e47300. doi:10.1371/journal.pone. 0047300

Drouault S, Corthier G, Ehrlich SD, Renault P (1999) Survival, physiology, and lysis of Lactococcus lactis in the digestive tract. Appl Environ Microbiol 65:4881-4886

Etzold S, Kober OI, MacKenzie DA, Tailford LE, Gunning AP, Walshaw J, Hemmings AM, Juge N (2014) Structural basis for adaptation of lactobacilli to gastrointestinal mucus: structure of Lactobacillus mucus binding protein. Environ Microbiol 16:888-903. doi:10.1111/ 1462-2920.12377

Finegold S, Sutter V, Mathisen G (1983) Normal indigenous intestinal flora. In: Hentges DJ (ed) Human intestinal microflora in health and disease. Academic Press, New York, pp 3-31

Gibbins HL, Proctor GB, Yakubov GE, Wilson S, Carpenter GH (2015) SIgA binding to mucosal surfaces is mediated by mucin-mucin interactions. PLoS One 10:e119677. doi:10.1371/journal.pone. 0119677

Gopal PK, Prasad J, Smart J, Gill HS (2001) In vitro adherence properties of Lactobacillus rhamnosus DR20 and Bifidobacterium lactis DR10 strains and their antagonistic activity against an enterotoxigenic Escherichia coli. Int J Food Microbiol 67:207-216. doi:10.1016/ S0168-1605(01)00440-8

Górecki RK, Koryszewska-Bagińska A, Gołębiewski M, Żylińska J, Grynberg M, Bardowski JK (2011) Adaptative potential of the Lactococcus lactis IL594 strain encoded in its 7 plasmids. PLoS One 6:e22238. doi:10.1371/journal.pone.0022238

Gouyer V, Wiede A, Buisine M-P, Dekeyser S, Moreau O, Lesuffleur T, Hoffmann W, Huet G (2001) Specific secretion of gel-forming mucins and TFF peptides in HT-29 cells of mucin-secreting phenotype. Biochim Biophys Acta 1539:71-84. doi:10.1016/S0167-4889(01) 00092-1

Gruzza M, Duval-Iflah Y, Ducluzeau R (1992) Colonization of the digestive tract of germ-free mice by genetically engineered strains of Lactococcus lactis: study of recombinant DNA stability. Microb Releases 1:165-171

Habimana O, Le Goff C, Juillard V, Bellon-Fontaine M-N, Buist G, Kulakauskas S, Briandet R (2007) Positive role of cell wall anchored proteinase PrtP in adhesion of lactococci. BMC Microbiol 7:36. doi: 10.1186/1471-2180-7-36

Hugentobler F, Di Roberto RB, Gillard J, Cousineau B (2012) Oral immunization using live Lactococcus lactis co-expressing LACK and IL-12 protects BALB/c mice against Leishmania major infection. Vaccine 30:5726-5732. doi:10.1016/j.vaccine.2012.07.004

Kasarełło K, Szczepankowska A, Kwiatkowska-Patzer B, Lipkowski AW, Gadamski R, Sulejczak D, Łachwa M, Biały M, Bardowski J (2016) Effect of recombinant Lactococcus lactis producing myelin peptides on neuroimmunological changes in rats with experimental allergic encephalomyelitis. Folia Neuropathol 3:249-258. doi:10. 5114/fn.2016.62534

Kebouchi M, Galia W, Genay M, Soligot C, Lecomte X, Awussi AA, Perrin C, Roux E, Dary-Mourot A, Le Roux Y (2016) Implication of sortase-dependent proteins of Streptococcus thermophilus in adhesion to human intestinal epithelial cell lines and bile salt tolerance. Appl Microbiol Biotechnol 100:3667-3679. doi:10.1007/s00253016-7322-1
Kechaou N, Chain F, Gratadoux J-J, Blugeon S, Bertho N, Chevalier C, Le Goffic R, Courau S, Molimard P, Chatel JM, Langella P, Bermudez-Humaran LG (2013) Identification of one novel candidate probiotic Lactobacillus plantarum strain active against influenza virus infection in mice by a large-scale screening. Appl Environ Microbiol 79:1491-1499. doi:10.1128/AEM.03075-12

Kimoto H, Nomura M, Kobayashi M, Mizumachi K, Okamoto T (2003) Survival of lactococci during passage through mouse digestive tract. Can J Microbiol 49:707-711. doi:10.1139/w03-092

Klijn N, Weerkamp AH, de Vos WM (1995) Genetic marking of Lactococcus lactis shows its survival in the human gastrointestinal tract. Appl Environ Microbiol 61:2771-2774

Lakshminarayanan B, Guinane CM, O'Connor PM, Coakley M, Hill C, Stanton C, O'Toole PW, Ross RP (2013) Isolation and characterization of bacteriocin-producing bacteria from the intestinal microbiota of elderly Irish subjects. J Appl Microbiol 114:886-898. doi:10. 1111/jam. 12085

Le DTL, Guérardel Y, Loubičre P, Mercier-Bonin M, Dague E (2011) Measuring kinetic dissociation/association constants between Lactococcus lactis bacteria and mucins using living cell probes. Biophys J 101:2843-2853. doi:10.1016/j.bpj.2011.10.034

Le DTL, Zanna S, Frateur I, Marcus P, Loubière P, Dague E, MercierBonin M (2012) Real-time investigation of the muco-adhesive properties of Lactococcus lactis using a quartz crystal microbalance with dissipation monitoring. Biofouling 28:479-490. doi:10.1080/ 08927014.2012.688103

Le DTL, Tran T-L, Duviau M-P, Meyrand M, Guérardel Y, Castelain M, Loubière P, Chapot-Chartier M-P, Dague E, Mercier-Bonin M (2013) Unraveling the role of surface mucus-binding protein and pili in muco-adhesion of Lactococcus lactis. PLoS One 8:e79850. doi:10.1371/journal.pone.0079850

Leenhouts KJ, Tolner B, Bron S, Kok J, Venema G, Seegers JFML (1991) Nucleotide sequence and characterization of the broad-host-range lactococcal plasmid pWVO1. Plasmid 26:55-66. doi:10.1016/ 0147-619X(91)90036-V

Lesuffleur T, Barbat A, Dussaulx E, Zweibaum A (1990) Growth adaptation to methotrexate of HT-29 human colon carcinoma cells is associated with their ability to differentiate into columnar absorptive and mucus-secreting cells. Cancer Res 50:6334-6343

Lesuffleur T, Porchet N, Aubert JP, Swallow D, Gum JR, Kim YS, Real FX, Zweibaum A (1993) Differential expression of the human mucin genes MUC1 to MUC5 in relation to growth and differentiation of different mucus-secreting HT-29 cell subpopulations. J Cell Sci 106:771-783

Lukić J, Strahinić I, Jovčić B, Filipić B, Topisirović L, Kojić M, Begović J (2012) Different roles for lactococcal aggregation factor and mucin binding protein in adhesion to gastrointestinal mucosa. Appl Environ Microbiol 78:7993-8000. doi:10.1128/AEM.02141-12

Maeda S, Gasson MJ (1986) Cloning, expression and location of the Streptococcus lactis gene for phospho- $\beta$-D-galactosidase. J Gen Microbiol 132:331-340

Maguin E, Prévost H, Ehrlich SD, Gruss A (1996) Efficient insertional mutagenesis in lactococci and other gram-positive bacteria. J Bacteriol 178:931-935

McNulty NP, Yatsunenko T, Hsiao A, Faith JJ, Muegge BD, Goodman AL, Henrissat B, Oozeer R, Cools-Portier S, Gobert G, Chervaux C, Knights D, Lozupone CA, Knight R, Duncan AE, Bain JR, Muehlbauer MJ, Newgard CB, Heath AC, Gordon JI (2011) The impact of a consortium of fermented milk strains on the gut microbiome of gnotobiotic mice and monozygotic twins. Sci Transl Med 3:106ra106. doi:10.1126/scitranslmed.3002701

Meyrand M, Guillot A, Goin M, Furlan S, Armalyte J, Kulakauskas S, Cortez-Perez NG, Thomas G, Chat S, Pechoux C (2013) Surface proteome analysis of a natural isolate of Lactococcus lactis reveals the presence of pili able to bind human intestinal epithelial cells. Mol Cell Proteomics 12:3935-3947. doi:10.1074/mcp.M113.029066 
Millette M, Dupont C, Archambault D, Lacroix M (2007) Partial characterization of bacteriocins produced by human Lactococcus lactis and Pediococccus acidilactici isolates. J Appl Microbiol 102:274-282. doi:10.1111/j.1365-2672.2006.03044.x

Radziwill-Bienkowska JM, Zochowska D, Bardowski J, Mercier-Bonin M, Kowalczyk M (2014) Lactococcus lactis IBB477 presenting adhesive and muco-adhesive properties as a candidate carrier strain for oral vaccination against influenza virus. Acta Biochim Pol 61: 603-607

Radziwill-Bienkowska JM, Le DTL, Szczesny P, Duviau M-P, Aleksandrzak-Piekarczyk T, Loubière $\mathrm{P}$, Mercier-Bonin M, Bardowski JK, Kowalczyk M (2016) Adhesion of the genomesequenced Lactococcus lactis subsp. cremoris IBB477 strain is mediated by specific molecular determinants. Appl Microbiol Biotechnol 100:9605-9617. doi:10.1007/s00253-016-7813-0

Rochet V, Rigottier-Gois L, Rabot S, Doré J (2004) Validation of fluorescent in situ hybridization combined with flow cytometry for assessing interindividual variation in the composition of human fecal microflora during long-term storage of samples. J Microbiol Methods 59:263-270. doi:10.1016/j.mimet.2004.07.012

Roy K, Meyrand M, Corthier G, Monnet V, Mistou M-Y (2008) Proteomic investigation of the adaptation of Lactococcus lactis to the mouse digestive tract. Proteomics 8:1661-1676. doi:10.1002/ pmic. 200700698

Salama M, Sandine W, Giovannoni S (1991) Development and application of oligonucleotide probes for identification of Lactococcus lactis subsp. cremoris. Appl Environ Microbiol 57:1313-1318

Schlundt J, Saadbye P, Lohmann B, Jacobsen BL, Nielsen EM (1994) Conjugal transfer of plasmid DNA between Lactococcus lactis strains and distribution of transconjugants in the digestive tract of gnotobiotic rats. Microb Ecol Health Dis 7:59-69. doi:10.3109/ 08910609409141574

Sengupta R, Altermann E, Anderson RC, McNabb WC, Moughan PJ, Roy NC (2013) The role of cell surface architecture of lactobacilli in host-microbe interactions in the gastrointestinal tract. Mediat Inflamm 2013:237921. doi:10.1155/2013/237921

Sławińska A, Siwek M, Żylińska J, Bardowski J, Brzezińska J, Gulewicz KA, Nowak M, Urbanowski M, Płowiec A, Bednarczyk M (2014) Influence of synbiotics delivered in ovo on immune organs development and structure. Folia Biol (Praha) 62:277-285. doi:10.3409/ fb62 3.277
Sperandio B, Fischer N, Chevalier-Curt MJ, Rossez Y, Roux P, Robbe Masselot C, Sansonetti PJ (2013) Virulent Shigella flexneri affects secretion, expression, and glycosylation of gel-forming mucins in mucus-producing cells. Infect Immun 81:3632-3643. doi:10.1128/ IAI.00551-13

Szatraj K, Szczepankowska AK, Sączyńska V, Florys K, Gromadzka B, Łepek K, Płucienniczak G, Szewczyk B, Zagórski-Ostoja W, Bardowski JK (2014) Expression of avian influenza haemagglutinin (H5) and chicken interleukin 2 (chIL-2) under control of the $p t c B$ promoter in Lactococcus lactis. Acta Biochim Pol 61:609-614

Turpin W, Humblot C, Noordine M-L, Thomas M, Guyot J-P (2012) Lactobacillaceae and cell adhesion: genomic and functional screening. PLoS One 7:e38034. doi:10.1371/journal.pone.0038034

Turpin W, Humblot C, Noordine M-L, Wrzosek L, Tomas J, Mayeur C, Cherbuy C, Guyot J-P, Thomas M (2013) Behavior of lactobacilli isolated from fermented slurry (ben-saalga) in gnotobiotic rats. PLoS One 8:e57711. doi:10.1371/journal.pone.0057711

van der Waaij D, Berghuis-de Vries JM, Lekkerkerk-van der Wees JEC (1971) Colonization resistance of the digestive tract in conventional and antibiotic-treated mice. J Hyg (Lond) 69:405-411

Vélez MP, De Keersmaecker SCJ, Vanderleyden J (2007) Adherence factors of Lactobacillus in the human gastrointestinal tract. FEMS Microbiol Lett 276:140-148. doi:10.1111/j.1574-6968.2007.00908. $\mathrm{X}$

Wang Y, Wang J, Dai W (2011) Use of GFP to trace the colonization of Lactococcus lactis $\mathrm{WH}-\mathrm{C} 1$ in the gastrointestinal tract of mice. J Microbiol Methods 86:390-392. doi:10.1016/j.mimet.2011.06.009

Watson D, Sleator RD, Hill C, Gahan CG (2008) Enhancing bile tolerance improves survival and persistence of Bifidobacterium and Lactococcus in the murine gastrointestinal tract. BMC Microbiol 8:176. doi:10.1186/1471-2180-8-176

Zhang C, Derrien M, Levenez F, Brazeilles R, Ballal SA, Kim J, Degivry M-C, Quéré G, Garault P, van Hylckama Vlieg JET, Garrett WS, Doré J, Veiga P (2016) Ecological robustness of the gut microbiota in response to ingestion of transient food-borne microbes. ISME J 10:2235-2245. doi:10.1038/ismej.2016.13

Zycka-Krzesinska J, Boguslawska J, Aleksandrzak-Piekarczyk T, Jopek J, Bardowski JK (2015) Identification and characterization of tetracycline resistance in Lactococcus lactis isolated from Polish raw milk and fermented artisanal products. Int J Food Microbiol 211: 134-141. doi:10.1016/j.ijfoodmicro.2015.07.009 